\begin{tabular}{|c|c|c|}
\hline BI & $\begin{array}{c}\text { BIODIK: Jurnal IImiah Pendidikan Biologi } \\
\text { ISSN 2580-0922 (online), ISSN 2460-2612 (print) } \\
\text { Volume 7, Nomor 01, Tahun 2021, Hal. 62-76 } \\
\text { Available online at: } \\
\text { https://online-journal.unja.ac.id/biodik }\end{array}$ & BIODIK $Q$ \\
\hline
\end{tabular}

Research Article

open access

\title{
Biotechnopreneurship: Model Pembelajaran untuk Meningkatkan Hasil Belajar dan Minat Berwirausaha Mahasiswa
}

\author{
(Biotechnopreneurship: Learning Models to Improve Student Learning Outcomes and \\ Entrepreneurial Interest)
}

\author{
Nur Hayati*, Lina Arifah Fitriyah
}

Prodi Pendidikan IPA Universitas Hasyim Asy'ari Tebuireng Jombang

Tebuireng, Jl. Irian Jaya No.55, Cukir, Kabupaten Jombang, Jawa Timur 61471-Indonesia

Corresponding Authors: nurhay.ht@gmail.com

\begin{tabular}{|c|c|}
\hline Informasi Artikel & ABSTRACT \\
\hline $\begin{array}{l}\text { Submit: } 23-10-2020 \\
\text { Diterima: } 20-02-2021 \\
\text { Dipublikasikan: } 14-03-2021\end{array}$ & $\begin{array}{l}\text { This research was a Classroom Action Research with two cycles, each cycle } \\
\text { consisting of planning, implementing, observing and reflecting. The aim of this study } \\
\text { is to improve student learning outcomes and entrepreneurial interest through } \\
\text { biotechnopreneurship-based learning models. This research was conducted in the } \\
\text { odd semester of 2018/2019. The subjects of this study were students class } 2016 \text { of } \\
\text { Natural Sciences Education Study Program of Hasyim Asy'ari (UNHASY) Tebuireng } \\
\text { Jombang, totaling } 14 \text { students. The research instrument was a learning outcome } \\
\text { assessment sheet and an entrepreneurial interest questionnaire. Data analysis was } \\
\text { carried out descriptively by calculating the score of learning outcomes and interest in } \\
\text { entrepreneurship in the cycle I and cycle II to determine an increase. The results } \\
\text { showed that the implementation of biotechnopreneurship-based learning models was } \\
\text { able to improve student learning outcomes and entrepreneurial interest. There was } \\
\text { an increase in student learning outcomes scores from the cycle I of } 73.07 \text { to } 77.35 \text { in } \\
\text { the cycle II. The percentage of completeness of learning outcomes increased from } \\
42.85 \% \text { in the cycle I to } 64.28 \% \text { in the cycle II. The score of interest in } \\
\text { entrepreneurship increased from } 69.77 \text { in the cycle I with neutral criteria, to } 77.09 \text { in } \\
\text { the cycle II with good criteria. } \\
\text { Keywords: Biotechnopreneurship, Biotechnology, Interest, Entrepreneurship }\end{array}$ \\
\hline Penerbit & ABSTRAK \\
\hline $\begin{array}{l}\text { Program Studi Pendidikan } \\
\text { Biologi, Fakultas Keguruan dan } \\
\text { Ilmu Pendidikan, Universitas } \\
\text { Jambi }\end{array}$ & $\begin{array}{l}\text { Penelitian ini merupakan Penelitian Tindakan Kelas dengan dua siklus, tiap siklus } \\
\text { terdiri atas tahap planning, implementing, observing dan reflecting. Adapun tujuan } \\
\text { penelitian ini adalah untuk meningkatkan hasil belajar dan minat berwirausaha } \\
\text { mahasiswa melalui model pembelajaran berbasis biotechnopreneurship. Penelitian } \\
\text { ini dilaksanakan pada semester ganjil } 2018 / 2019 \text { dengan subjek penelitian } \\
\text { mahasiswa prodi pendidikan IPA Universitas Hasyim Asy'ari (UNHASY) Tebuireng } \\
\text { Jombang angkatan } 2016 \text { yang berjumlah } 14 \text { orang. Instrumen penelitian berupa } \\
\text { lembar penilaian hasil belajar dan angket minat berwirausaha. Analisis data } \\
\text { dilakukan secara deskriptif dengan menghitung skor hasil belajar dan minat } \\
\text { berwirausaha pada siklus I dan siklus II untuk mengetahui adanya peningkatan. Hasil } \\
\text { penelitian menunjukkan bahwa implementasi model pembelajaran berbasis } \\
\text { biotechnopreneurship mampu meningkatkan hasil belajar dan minat berwirausaha } \\
\text { mahasiswa. Terjadi peningkatan skor hasil belajar mahasiswa dari siklus I sebesar } \\
73.07 \text { menjadi } 77.35 \text { pada siklus II. Prosentase ketuntasan hasil belajar meningkat } \\
\text { dari } 42.85 \% \text { pada siklus I menjadi } 64.28 \% \text { pada siklus II. Skor minat berwirausaha } \\
\text { meningkat dari } 69.77 \text { pada siklus I dengan kriteria netral, menjadi } 77.09 \text { pada siklus } \\
\text { II dengan kriteria baik. } \\
\text { Kata Kunci: Biotechnopreneurship, Bioteknologi, Minat, Kewirausahaan }\end{array}$ \\
\hline
\end{tabular}




\section{PENDAHULUAN}

Saat ini pembahasan mengenai wirausaha menjadi hal yang penting, karena: 1) meningkatnya jumlah pengangguran, salah satunya disebabkan oleh kecenderungan mahasiswa untuk lebih memilih menjadi pencari kerja (job seeker) daripada pembuka lapangan kerja (job creator), dan 2) banyaknya wirausaha berbanding dengan kemajuan bangsa, di mana semakin banyak jumlah pengusaha diikuti dengan semakin tingginya aktivitas perekonomian bangsa (Widyastuti et al., 2016). Wirausaha memiliki peran penting dalam perekonomian negara karena melalui pemikirannya, seorang wirausaha akan mampu menciptakan peluang usaha yang dapat mengurangi angka pengangguran sehingga dapat meningkatkan perekonomian nasional. Wirausaha merupakan pengendali kunci keberhasilan suatu usaha (Nur et al., 2014; Islam et al., 2011).

Huang \& Knight (2017) menyampaikan bahwa wirausaha atau entrepreneur adalah seseorang yang memiliki keahlian dalam mengambil keputusan yang berbeda dengan orang lain untuk memanfaatkan sumber daya yang ada di sekitarnya agar lebih berguna daripada sebelumnya. Menurut Volery et al. (2013), wirausaha merupakan seseorang yang mempunyai kemampuan dalam mengembangkan sesuatu yang baru dengan jalan memanfaatkan sumber daya di sekitarnya. Seorang wirausahawan harus mampu melihat setiap peluang untuk menganalisis dan mengambil keputusan dalam mencapai keuntungan bagi dirinya sendiri atau lingkungan sekitar dan kelangsungan usahanya sebelum peluang tersebut dimanfaatkan oleh orang lain (Kusumajanto, 2015). Fakta menunjukkan bahwa jumlah wirausaha yang ada di Indonesia saat ini mencapai 400 ribu jiwa, atau kurang dari $1 \%$ populasi penduduk Indonesia yang berkisar 200 juta jiwa. Berbeda dengan jumlah wirausaha di Amerika Serikat sebesar $11,5 \%$ dari populasi penduduknya, Singapura dengan jumlah wirausaha sebanyak 7,2\% dan Malaysia sebesar 5\% (Aidha, 2016).

Berkaitan dengan hal tersebut, budaya etos kewirausahaan belum sepenuhnya tertanam di kalangan mahasiswa. Selama di bangku kuliah, mahasiswa cenderung tidak mempunyai rencana berwirausaha namun mengharapkan pekerjaan dengan penghasilan tinggi serta mapan setelah lulus (Zubaedi, 2015) . Lulusan perguruan tinggi tidak bisa jika hanya bergantung pada hard skill tetapi juga harus memiliki soft skills, salah satunya adalah jiwa entrepreneurship (Afriadi \& Yuni, 2018). Jiwa kewirausahaan sangat dibutuhkan sebagai kecakapan hidup (life skill) agar mampu hidup secara mandiri dalam masyarakat.

Menjadi wirausaha bukan merupakan status namun lebih mengarah pada perubahan karakter, kemampuan dan pola pikir (Widyastuti et al., 2016). Penanaman karakter dan nilai-nilai kewirausahaan harus dilakukan sejak dini, bukan hanya di kalangan wiraswasta dan usahawan namun juga melalui pendidikan di sekolah (Isrososiawan, 2013; Okorie et al., 2014; (Suyahman, 2017). Pengembangan entrepreneurship di sekolah memiliki tujuan supaya peserta didik: 1). mengetahui dunia usaha di lingkungan masyarakat; 2). mampu berwirausaha sesuai bidangnya; 3). mengaplikasikan sikap kerja prestatif; 4). mewujudkan perilaku dan sikap wirausaha (Anwar et al., 2012).

Perguruan tinggi memiliki peran penting dalam meningkatkan mutu pendidikan demi kemajuan bangsa, sehingga pendidikan tinggi harus berupaya untuk menciptakan wirausaha (Budiati et al., 2012) 
dengan menghasilkan lulusan yang mampu membuka lapangan pekerjaan, bukan hanya mencari lapangan pekerjaann (Hasni, 2018). Perguruan tinggi ikut bertanggung jawab dalam menyiapkan dan memberikan motivasi kepada lulusannya untuk bersedia memilih berwirausaha dengan professional (Okorie et al., 2014) dan menjadi wirausaha muda (Budiati et al., 2012). Berkaitan dengan hal tersebut, perguruan tinggi diharuskan membekali mahasiswa dengan pendidikan kewirausahaan.

Pendidikan kewirausahaan bukan hanya memberikan teori berkaitan dengan konsep kewirausahaan tetapi juga membentuk perilaku, sikap, dan pola pikir entrepreneur seperti jiwa kemandirian, inovatif, ulet, mampu bernegosiasi dan berani menghadapi risiko (Ningsih, 2017; (Lestari \& Wijaya, 2012). Dengan jiwa wirausaha yang terus berkembang di kalangan mahasiswa, diharapkan mampu meningkatkan orientasi mahasiswa dalam wirausaha (Mopangga, 2015) dan mengarahkan mahasiswa untuk menjadikan berwirausaha sebagai pilihan karir (Lestari \& Wijaya, 2012). Selain itu, melalui pembelajaran kewirausahaan diharapkan mampu mengurangi angka pengangguran, khususnya dari lulusan perguruan tinggi (sarjana dan diploma) (Aidha, 2016) .

Untuk mencapai visi Universitas Hasyim Asy'ari (UNHASY) sebagai pusat pengembangan ilmu pengetahuan berbasis pesantren dan kewirausahaan, maka melalui matakuliah Kewirausahaan diharapkan mahasiswa bukan sekedar memiliki pengetahuan tetapi juga mampu mengaplikasikan ilmunya untuk dapat berwirausaha. Fakta yang muncul menunjukkan mahasiswa belum mampu menghasilkan produk kewirausahaan yang sesuai dengan bidang ilmunya. Sebagai contoh, mahasiswa prodi pendidikan IPA menjual produk berupa jilbab, gorengan, pisang coklat. Hal ini bisa dikaitkan dengan hasil wawancara dengan mahasiswa prodi pendidikan IPA angkatan 2016 yang menunjukkan bahwa semua mahasiswa dalam kelas tersebut belum pernah membuat produk biologi konvensional seperti tempe, tape, nata maupun yoghurt. Pemahaman konsep bioteknologi konvensional penting dikuasai mahasiswa prodi pendidikan IPA UNHASY agar dapat menerapkan praktikum dengan baik sehingga dihasilkan produk yang berkualitas baik. Mahasiswa juga harus dibekali dengan jiwa kewirausahaan untuk menumbuhkan minat berwirausaha dalam menciptakan produk usaha.

Menurut Kusumajanto (2015), minat merupakan suatu kondisi dari rasa cinta, kesenangan, ketertarikan atau kecenderungan untuk mengarahkan atau memberi perhatian pada hal-hal, peristiwa, benda dan orang dan itu sangat penting atau bermakna bagi individu. Minat berwirausaha terlihat dari kesediaan seseorang untuk bekerja keras dan rajin mencapai kemajuan usahanya, kemauan menanggung resiko yang berhubungan dengan mencoba tindakan, mau mengambil jalan dan jalan yang baru, kemauan untuk hidup hemat, kemauan belajar yang terjadi.

Berdasarkan hasil visitasi oleh tim assesor pada saat akreditasi prodi pendidikan IPA pada bulan Maret 2017, terdapat beberapa masukan di antaranya hasil akhir perkuliahan Kewirausahaan seharusnya bukan sekedar menciptakan produk usaha, tapi juga harus merupakan aplikasi dari konsep materi IPA, oleh karena itu diperlukan integrasi antara matakuliah kewirausahaan dengan matakuliah bidang IPA seperti matakuliah Bioteknologi. Matakuliah Bioteknologi merupakan salah satu matakuliah umum yang wajib ditempuh oleh mahasiswa prodi pendidikan IPA UNHASY semester V. Matakuliah ini terdiri atas 2 SKS yang mencakup konsep dasar bioteknologi, bioteknologi konvensional dan bioteknologi modern, peran dan contoh-contoh bioteknologi, etika dalam bioteknologi. Matakuliah Bioteknologi dapat dilaksanakan berupa teori maupun praktikum dengan menghadirkan ke dalam kelas mengenai contoh penerapan bioteknologi dalam kehidupan. Melalui matakuliah Bioteknologi, mahasiswa dapat dibekali dengan pengalaman belajar berupa pembuatan produk bioteknologi. Dengan demikian, solusi yang dapat diberikan adalah dengan memaksimalkan kegiatan praktikum bioteknologi 
konvensional pada matakuliah Bioteknologi melalui pembelajaran berbasis kewirausahaan atau disebut biotechnopreneurship.

Integrasi kewirausahaan dalam matakuliah bioteknologi merupakan bentuk pendekatan kontekstual. Afriadi \& Yuni (2018) memaparkan bahwa setiap cabang biologi mempuyai karakteristik untuk dapat dikembangkan menjadi peluang bisnis sesuai dengan minat dan kreativitas yang dimiliki mahasiswa. Prinsip pembelajaran biotechnopreneurship adalah pelaksanaan pembelajaran berupa praktikum bioteknologi konvensional untuk menghasilkan produk usaha yang bernilai ekonomi. Fitri et al. (2014) memaparkan bahwa pembelajaran berbasis bioentrepreneurship memuat inovasi pengolahan makanan melalui kegiatan praktikum bioteknologi konvensional yang berbasis kewirausahaan (entrepreneurship skill). Produk yang dihasilkan dari kegiatan praktikum mampu menumbuhkan kreativitas peserta didik dalam berwirausaha sehingga berpotensi mengembangkan keterampilan proses peserta didik.

Berbagai hasil penelitian mengenai pembelajaran biologi berbasis kewirausahaan telah dilakukan. Penelitian Subekti \& Hidayati (2013) menunjukkan bahwa prototipe pembelajaran biotechnopreneurship yang merupakan integrasi antara biologi, teknologi dan kewirausahaan mampu mendukung kompetensi calon guru sains dan budaya berwirausaha. Penelitian yang dilakukan Anwar et al. (2012) membuktikan bahwa pembelajaran biologi dengan pendekatan bioenterpreneurship dapat meningkatkan keterampilan proses sains dan minat berwirausaha siswa. Hasil penelitian Fitriah (2013) menunjukkan bahwa pendekatan pembelajaran bioentrepreneurship mampu meningkatkan life skills dan minat berwirausaha siswa.

Melalui praktikum bioteknologi konvensional, mahasiswa diharapkan bukan hanya mengetahui tetapi juga terampil menghasilkan berbagai produk untuk bekal berwirausaha sesuai bidang ilmunya. Adapun praktikum bioteknologi konvensional yang bisa dilaksanakan yaitu pembuatan tempe, pembuatan tape, pembuatan nata dan pembuatan yoghurt. Hasil praktikum tersebut dapat diolah lagi menjadi produk usaha yang bernilai tinggi. Penelitian ini perlu dilakukan karena penelitian serupa belum pernah dilakukan pada mahasiswa prodi pendidikan IPA UNHASY untuk meningkatkan hasil belajar dan minat berwirausaha mahasiswa.

\section{METODE PENELITIAN}

Penelitian ini merupakan penelitian tindakan kelas dengan dua siklus. Tiap siklus terdiri atas tahap planning, implementing, observing dan reflecting. Tujuan penelitian ini untuk meningkatkan hasil belajar dan minat berwirausaha mahasiswa melalui praktikum bioteknologi konvensional. Lokasi penelitian berada di Laboratorium IPA, ruang 1.03, Gedung B Universitas Hasyim Asy'ari Tebuireng Jombang, Jalan Irian Jaya No. 55 Tebuireng Tromol Pos IX Jombang Jawa Timur. Penelitian ini diaplikasikan pada matakuliah bioteknologi semester ganjil 2018/2019, dengan topik bioteknologi konvensional. Penelitian ini diterapkan pada mahasiswa prodi pendidikan IPA angkatan 2016 yang berjumlah 14 orang.

Teknik pengumpulan data melalui observasi, dokumentasi, tes, dan angket. Instrumen yang digunakan berupa lembar penilaian hasil belajar mahasiswa dan angket minat berwirausaha. Lembar penilaian hasil belajar meliputi soal 20 pilihan ganda berjumlah dan 5 soal uraian, sedangkan angket minat berwirausaha berjumlah 15 pernyataan. Adapun indikator minat berwirausaha mengacu pada Kusumajanto (2015) yang terdiri atas: 1) keinginan untuk berwirausaha, 2) ketertarikan untuk mendirikan usaha, 3) kesenangan pada kegiatan berwirausaha, 4) perhatian pada kegiatan 
kewirausahaan, 5) kesediaan untuk bekerja keras, 6) kesediaan untuk mengembangkan usaha, dan 7) kemauan untuk menanggung resiko usaha. Adapun instrumen lembar penilaian hasil belajar ini telah divalidasi oleh dosen prodi pendidikan IPA UNHASY, sedangkan angket minat berwirausaha telah divalidasi oleh dosen matakuliah Kewirausahaan UNHASY.

Analisis data hasil belajar dilakukan secara deskriptif dengan menghitung skor hasil belajar siklus I dan siklus II. Hasil belajar dikatakan tuntas apabila skor yang didapatkan $\geq 75$. Perhitungan angket minat berwirausaha menurut skala Likert berdasarkan skor pilihan jawaban Sangat Setuju (SS) = skor 4, Setuju $(\mathrm{S})=$ skor 3, Kurang Setuju $(\mathrm{KS})=$ skor 2, dan Tidak Setuju $(T S)=$ skor 1. Kriteria minat berwirausaha ditentukan berdasarkan Tabel 1.

Tabel 1. Kriteria Minat Berwirausaha

\begin{tabular}{ll}
\hline Interval (\%) & Kriteria Minat Berwirausaha \\
\hline $20 \%-36 \%$ & Sangat rendah \\
\hline $37 \%-53 \%$ & Rendah \\
\hline $54 \%-70 \%$ & Netral \\
\hline $71 \%-87 \%$ & Tinggi \\
\hline $88 \%-100 \%$ & Sangat tinggi \\
\hline Diadaptasi dari Rahayu (2011) &
\end{tabular}

Penelitian ini diawali dengan tahap persiapan kemudian dilanjutkan dengan tahap implementasi. Tahap persiapan berupa observasi kegiatan pembelajaran untuk mengetahui permasalahan yang terjadi di kelas. Setelah itu dilanjutkan penyusunan perangkat pembelajaran berupa Rencana Pembelajaran Semester (RPS) dan petunjuk praktikum, serta instrumen penelitian yang berupa lembar penilaian hasil belajar dan angket minat berwirausaha. Tahap selanjutnya adalah pembelajaran siklus I melalui implementasi pembelajaran berbasis biotechnopreneurship. Di akhir pembelajaran siklus I, mahasiswa diberi instrumen awal untuk mengetahui hasil belajar dan minat berwirausaha awal. Setelah dilakukan refleksi terhadap pembelajaran siklus I, dilanjutkan pembelajaran berbasis biotechnopreneurship siklus II. Pada akhir siklus II, mahasiswa diberi instrumen kembali untuk mengukur hasil belajar dan minat berwirausaha setelah pembelajaran berbasis biotechnopreneurship. Skor hasil belajar dan minat berwirausaha siklus I dan siklus II kemudian dibandingkan untuk mengetahui adanya peningkatan.

\section{HASIL PENELITIAN DAN PEMBAHASAN}

Data hasil penelitian ini dipaparkan sebagai berikut.

\section{Siklus I}

Siklus I terdiri atas 2 pertemuan yang meliputi tahap planning, implementing, observing dan reflecting.

\section{Planning}

Kegiatan yang dilakukan pada tahap planning adalah menyusun perangkat pembelajaran dan instrumen penelitian berupa lembar penilaian hasil belajar dan angket minat berwirausaha. Sebelumnya mahasiswa telah dibagi dalam kelompok.

\section{Implementing}

Pada tahap implementing, diterapkan biotechnopreneurship pada matakuliah bioteknologi yang berupa kegiatan praktikum pembuatan nata. Praktikum pembuatan nata dilakukan pada hari Kamis, 27 
September 2018. Adapun topik yang diambil adalah mengenai pembuatan nata dari berbagai buahbuahan. Jenis buah-buahan yang digunakan sebagai bahan baku nata adalah semangka dan tomat.

\section{Observing}

Pada tahap observing dilakukan pengamatan terhadap kegiatan pembelajaran. Pengamatan dibantu oleh dua orang observer yang berasal dari dosen IPA Universitas Hasyim Asy'ari Tebuireng Jombang. Pembuatan nata pada penelitian ini memanfaatkan bakteri Acetobacter xylinum yang didapatkan dari laboratorium budidaya jamur Universitas Muhammadiyah Malang (UMM). Nata merupakan lapisan selulosa hasil metabolit sekunder dari proses fermentasi mikroorganisme Acetobacter xylinum (Widiyaningrum et al., 2017). Umumnya nata yang banyak beredar di masyarakat berasal dari air kelapa atau disebut nata de coco, namun beberapa bahan lain juga digunakan untuk pembuatan nata seperti air cucian beras dan sari buah-buahan (Angraini et al., 2020). Pada awalnya diketahui Acetobacter xylinum merupakan spesies bakteri yang mampu berkembang dalam air kelapa, tetapi kemudian didapatkan informasi bahwa bakteri tersebut juga dapat hidup dan melakukan aktivitas fermentasi pada substrat yang mengandung glukosa. Hasil fermentasi bakteri Acetobacter xylinum dalam medium yang mengandung glukosa tersebut menghasilkan nata (Angraini et al., 2020). Pada kegiatan ini, mahasiswa menggunakan buah semangka dan tomat sebagai bahan baku nata. Menurut Fifendy \& Annisah (2012), kandungan karbohidrat dalam semangka dapat dimanfaatkan untuk bahan pembuatan nata de citrullus.

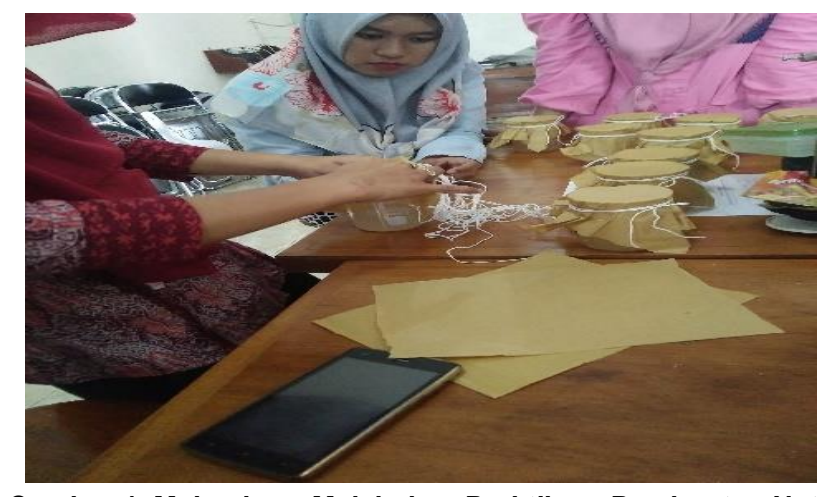

\section{Reflecting}

Gambar 1. Mahasiswa Melakukan Praktikum Pembuatan Nata

Setelah menerapkan pembelajaran berbasis biotechnopreneurship selanjutnya adalah melakukan refleksi terhadap pembelajaran. Hasil refleksi dan evaluasi digunakan untuk perbaikan pembelajaran. Pada siklus I yang telah dilakukan, diketahui bahwa hasil belajar kognitif siswa belum semuanya mencapai ketuntasan sehingga perlu diadakan siklus II. Adapun permasalahan yang ditemukan pada siklus I sebagai berikut.

1) Mahasiswa belum semuanya terlibat dalam kegiatan praktikum. Masih terdapat mahasiswa yang bermain handphone dan ada juga yang duduk diam sambil memperhatikan mahasiswa lain praktikum.

2) Beberapa mahasiswa tampak masih kebingungan dan belum paham langkah-langkah kegiatan pembuatan nata.

3) Masih terdapat mahasiswa yang bergurau ketika praktikum.

Berdasarkan permasalahan yang terjadi selanjutnya dilakukan upaya perbaikan terhadap proses pembelajaran sebagai berikut.

1) Dosen melakukan pendekatan pada mahasiswa yang kurang aktif agar lebih terlibat dalam pembelajaran. 
2) Dosen memberikan penjelasan kembali konsep dan langkah-langkah pembuatan nata agar mahasiswa menjadi lebih paham.

3) Dosen melakukan pendekatan untuk mengkondisikan mahasiswa yang bergurau dan belum fokus ketika praktikum.

\section{Siklus II}

Siklus II terdiri atas tahap planning, implementing, observing dan reflecting. Pembelajaran pada siklus II merupakan hasil refleksi dari siklus I.

\section{Planning}

Pada dasarnya, tahap planning pada siklus II adalah sama dengan pada siklus I yaitu menyiapkan perangkat pembelajaran dan instrumen penelitian.

\section{Implementing}

Pada tahap implementing diterapkan pembelajaran berbasis biotechnopreneurship melalui praktikum pengolahan nata. Kegiatan pengolahan nata dilakukan dua minggu setelah nata dipanen, yaitu pada tanggal 11 Oktober 2018.

\section{Observing}

Pada tahap observing dilakukan pengamatan terhadap kegiatan pengolahan nata. Sebelum dilakukan pengolahan nata, mahasiswa melakukan pengukuran terhadap berat dan tebal lapisan nata yang dihasilkan dari buah semangka dan tomat bersama dengan anggota kelompok. Adapun nata yang dihasilkan seperti dipaparkan pada Gambar 2.

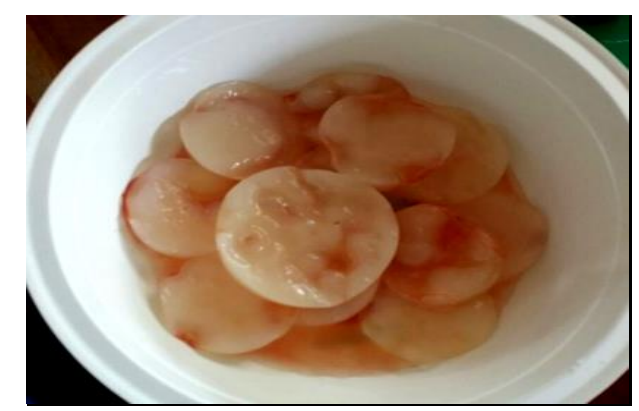

Gambar 2. Nata Hasil Praktikum

Tabel 1. Hasil Pengukuran Lapisan Nata

\begin{tabular}{|c|c|c|c|c|c|}
\hline $\begin{array}{l}\text { Bahan Sari } \\
\text { Buah }\end{array}$ & Ulangan & $\begin{array}{l}\text { Berat Nata } \\
\text { (gram) }\end{array}$ & $\begin{array}{l}\text { Rata-rata } \\
\text { Berat Nata } \\
\text { (gram) }\end{array}$ & $\begin{array}{l}\text { Tebal Nata } \\
(\mathrm{mm})\end{array}$ & $\begin{array}{l}\text { Rata-rata } \\
\text { Tebal Nata } \\
(\mathrm{mm})\end{array}$ \\
\hline \multirow{3}{*}{ Semangka } & 1 & 100 & \multirow{3}{*}{96,3} & 34 & \multirow{3}{*}{32,3} \\
\hline & 2 & 99 & & 30 & \\
\hline & 3 & 90 & & 33 & \\
\hline \multirow{3}{*}{ Tomat } & 1 & 48 & \multirow{3}{*}{41} & 10 & \multirow{3}{*}{15} \\
\hline & 2 & 50 & & 20 & \\
\hline & 3 & 25 & & 15 & \\
\hline
\end{tabular}

Berdasarkan Tabel 1, diketahui bahwa terdapat perbedaan berat dan ketebalan lapisan nata yang terbentuk dari buah semangka dan tomat. Lapisan nata yang berasal dari sari buah semangka memiliki rata-rata berat dan ketebalan yang lebih besar dibandingkan lapisan nata yang berasal dari sari buah tomat, yaitu $96,3 \mathrm{gr}$ dan $32,3 \mathrm{~mm}$. Lapisan nata yang berasal dari sari buah tomat memiliki 
rata-rata berat dan ketebalan $41 \mathrm{gr}$ dan $15 \mathrm{~mm}$. Ketebalan, berat dan kadar serat dalam nata dipengaruhi oleh kandungan glukosa pada masing-masing buah-buahan. Lebih lanjut dijelaskan bahwa pembentukan nata dipengaruhi oleh kandungan karbohidrat, suhu fermentasi, lama fermentasi, tingkat keasaman medium (pH), konsentrasi starter, sumber nitrogen, sumber karbon (Anam et al., 2019; Fifendy \& Annisah, 2012). Praktikum pembuatan nata dalam penelitian ini menggunakan asam cuka glasial dan air rebusan kecambah kacang hijau. Asam cuka glasial untuk memenuhi derajat keasaman yang dibutuhkan Acetobacter xylinum (pH 3-4) dan air rebusan kecambah kacang hijau sebagai penyedia senyawa nitrogen untuk nutrisi pertumbuhan bakteri Acetobacter xylinum.

Natalia \& Parjuningtyas (2009) menyatakan bahwa terbentuknya nata berasal dari pengambilan glukosa dari larutan atau sari buah-buahan oleh Acetobacter xylinum. Selanjutnya terjadi penggabungan glukosa dengan asam lemak yang membentuk jalinan selulosa di permukaan medium. Bakteri tersebut akan memproduksi enzim ekstraseluler yang mampu membentuk (mempolimerisasi) zat gula (glukosa) menjadi homopolimer selulosa (Widiyaningrum et al., 2017). Selanjutnya dari selulosa yang dihasilkan akan terbentuk jaringan mikrofibril panjang. Selama proses fermentasi juga dihasilkan gelembung $\mathrm{CO}_{2}$ yang melekat pada jaringan tersebut yang mengakibatkan jaringan terdorong ke permukaan cairan (Natalia \& Parjuningtyas, 2009). Rangkaian selulosa yang panjang tersebut berbentuk padat dan berwarna putih atau transparan yang dikenal sebagai nata (Widiyaningrum et al., 2017).

Pada penelitian ini, larutan nata disimpan di dalam tempat gelap dan tidak terkena cahaya matahari langsung yaitu dalam lemari selama 2 minggu, tujuannya agar fermentasi berlangsung optimal. Ketika proses fermentasi juga harus dijauhkan dari goncangan yang dapat merusak lapisan nata yang terbentuk. Adanya goncangan menyebabkan lapisan lama yang sudah terbentuk tidak dapat bersatu dengan lapisan baru sehingga ketebalan lapisan nata menjadi tidak maksimal. Selain itu juga harus diupayakan agar tempat fermentasi terhindar dari sumber panas dan tidak mudah terkontaminasi. Fifendy \& Annisah (2012) memaparkan bahwa selain dipengaruhi ketebalan selulosa, serat selulosa yang dihasilkan juga ditentukan oleh kekompakan ikatan. Makin kompak ikatan selulosa, makin tebal seratnya. Setelah melakukan pengukuran terhadap berat dan lapisan nata selanjutnya mahasiswa melakukan pengolahan nata. Produk yang dihasilkan dari kegiatan praktikum mahasiswa kemudian diolah lagi untuk dijadikan produk usaha sesuai kreativitas mahasiswa. Berikut disajikan gambar kegiatan pengolahan nata.

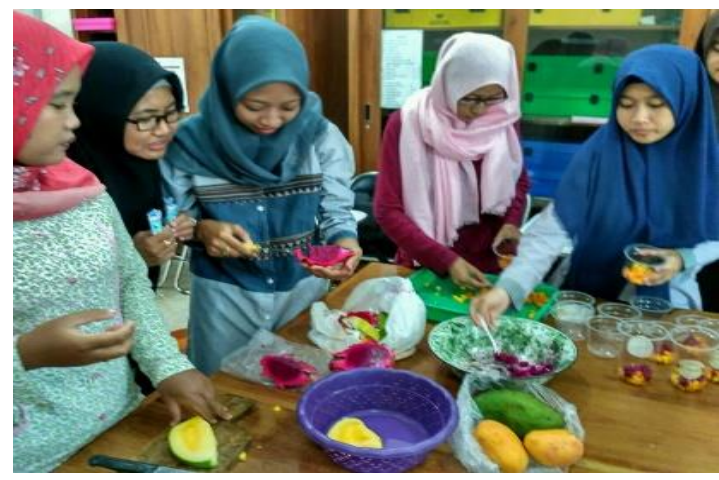

Gambar 3. Mahasiswa Melakukan Pengolahan Nata

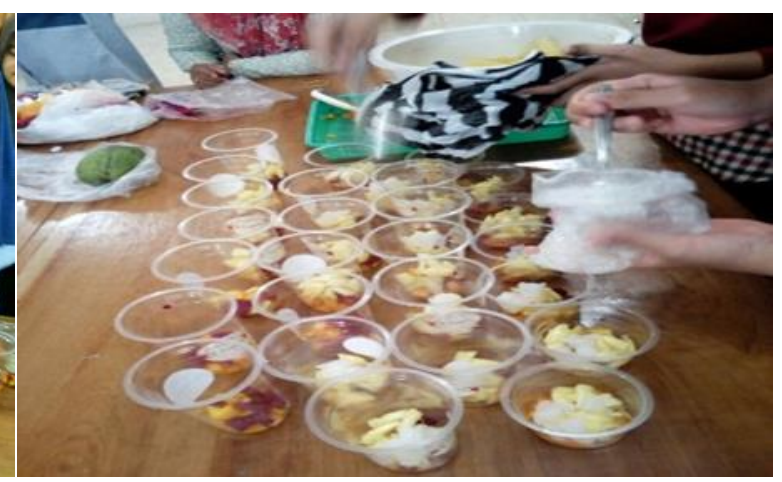

Gambar 4. Hasil Pengolahan Nata 
Pada saat pengolahan nata, mahasiswa tidak berdasarkan anggota kelompok ketika praktikum, namun kegiatan pengolahan nata dilakukan secara bersama-sama satu kelas. Adapun hasil olahan tersebut berupa es buah nata dengan penambahan berbagai buahdan larutan sirup. Sebelumnya mahasiswa telah menyiapkan dari rumah berbagai alat dan bahan yang dibutuhkan untuk pengolahan nata yang kemudian dibawa ke kelas. Produk olahan nata selanjutnya dipasarkan oleh mahasiswa di lingkungan kampus UNHASY. Pengolahan nata menjadi es buah nata dapat menambah nilai jual nata sebagai produk makanan yang lebih enak dan menarik tanpa mengurangi kandungan gizi nata, sehingga dapat dijadikan produk usaha oleh mahasiswa.

\section{Reflecting}

Berdasarkan hasil refleksi pembelajaran pada siklus II, didapatkan data meliputi: (1) Hasil pengamatan terhadap pembelajaran pada siklus II menunjukkan bahwa mahasiswa telah mampu melakukan praktikum pembuatan nata dari buah semangka dan tomat dengan baik yang ditunjukkan dengan ketebalan dan berat lapisan nata yang dihasilkan. (2) Mahasiswa telah mampu melakukan pengolahan nata dengan baik. (3) Semua mahasiswa terlibat aktif dalam pembelajaran. (4) Mahasiswa lebih mudah dikondisikan dan lebih fokus melakukan setiap langkah pembelajaran. (5) Mahasiswa terlihat antusias dalam melakukan pengolahan nata.

\section{Hasil Belajar}

Hasil belajar yang dimaksud dalam penelitian ini adalah skor hasil belajar kognitif mahasiswa pada matakuliah bioteknologi setelah praktikum pembuatan nata dan pengolahan nata. Analisis data penelitian menunjukkan bahwa terjadi peningkatan skor hasil belajar mahasiswa dari siklus I ke siklus II. Data hasil belajar mahasiswa disajikan dalam Tabel 2.

Tabel 2. Data Skor Hasil Belajar Mahasiswa

\begin{tabular}{|c|c|c|c|c|c|}
\hline \multirow{2}{*}{ No. } & \multirow{2}{*}{ Kode Mahasiswa } & \multicolumn{4}{|c|}{ Skor Hasil Belajar } \\
\hline & & Siklus I & Keterangan & Siklus II & Keterangan \\
\hline 1. & AS & 78 & Tuntas & 82 & Tuntas \\
\hline 2. & SL & 63 & Tidak tuntas & 81 & Tuntas \\
\hline 3. & EPA & 68 & Tidak tuntas & 76 & Tuntas \\
\hline 4. & AGB & 73 & Tidak tuntas & 70 & Tidak tuntas \\
\hline 5. & EKTW & 84 & Tuntas & 79 & Tuntas \\
\hline 6. & $\mathrm{NAFH}$ & 72 & Tidak tuntas & 80 & Tuntas \\
\hline 7. & $\mathrm{Al}$ & 75 & Tuntas & 68 & Tidak tuntas \\
\hline 8. & DMP & 66 & Tidak tuntas & 72 & Tidak tuntas \\
\hline 9. & DNNF & 75 & Tuntas & 73 & Tidak tuntas \\
\hline 10. & RA & 70 & Tidak tuntas & 88 & Tuntas \\
\hline 11. & UM & 80 & Tuntas & 84 & Tuntas \\
\hline 12. & Su & 64 & Tidak tuntas & 78 & Tuntas \\
\hline 13. & NF & 81 & Tuntas & 85 & Tuntas \\
\hline \multirow[t]{3}{*}{14.} & FD & 74 & Tidak tuntas & 67 & Tidak tuntas \\
\hline & Rerata & 73.07 & & 77.35 & \\
\hline & $\%$ Ketuntasan & 42.85 & & 64.28 & \\
\hline
\end{tabular}

Keterangan: $\mathrm{KKM}=\geq 75$

Untuk lebih meringkas penyajian data skor hasil belajar mahasiswa,dapat dilihat seperti pada Gambar 5. 


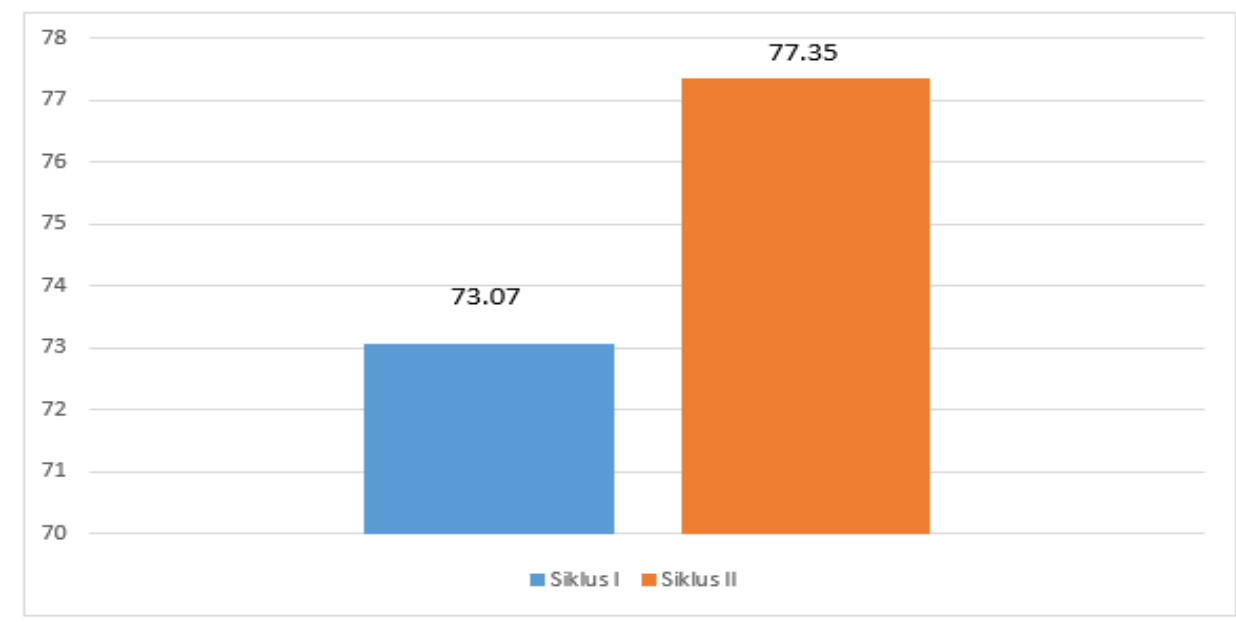

Gambar 5. Rerata Skor Hasil Belajar

Berdasarkan Tabel 2 diketahui bahwa rata-rata skor hasil belajar mahasiswa pada siklus I sebesar 73.07 sedangkan pada siklus II sebesar 77.35 sehingga terjadi peningkatan sebesar 4.28. Berikutnya disajikan grafik prosentase ketuntasan hasil belajar pada Gambar 6.

\section{Prosentase Ketuntasan Hasil belajar}

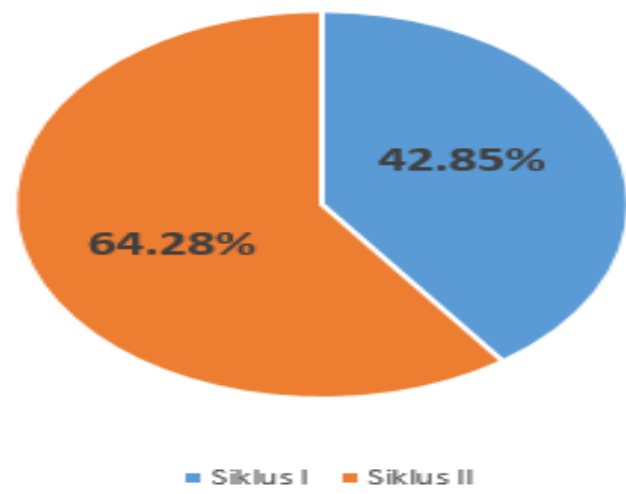

Gambar 6. Prosentase Ketuntasan Hasil Belajar

Adanya peningkatan hasil belajar mahasiswa karena model pembelajaran biotechnopreneurship menjadikan kegiatan pembelajaran lebih bermakna. Hasil penelitian ini sejalan dengan hasil penelitian (Machin, 2012) yang juga menjelaskan bahwa aplikasi pembelajaran bioteknologi berbasis kewirausahaan mampu memberikan dampak positif pada hasil belajar dan sikap berwirausaha siswa. Pembelajaran biologi berbasis kewirausahaan menghubungkan pembelajaran dengan kehidupan nyata dalam masyarakat dengan menghadirkan berbagai produk bioteknologi konvensional ke dalam kelas sehingga memberikan kebermaknaan belajar bagi peserta didik. Pada penelitian ini, mahasiswa mendapatkan pengalaman langsung dalam pembuatan nata yang sebelumnya tidak pernah dilakukan. Selain itu, model pembelajaran biotechnopreneurship memungkinkan terciptanya variasi model pembelajaran sehingga pembelajaran menjadi lebih menarik, tidak membosankan dan mahasiswa lebih mudah memahami materi.

Model pembelajaran biotechnopreneurship juga berpotensi merangsang aktivitas belajar sehingga menjadikan mahasiswa terlibat langsung dalam pembelajaran. Penelitian Fitri et al., (2014) 
melalui pengembangan LKS bioentrepeneurship pada pembuatan nata de lerri menjadikan siswa aktif dalam pembelajaran. Model pembelajaran biotechnopreneurship memungkinkan mahasiswa tidak hanya memahami konsep bioteknologi konvensional namun juga dapat melakukan langkah-langkah praktikum. Agar dapat melakukan langkah-langkah praktikum dengan baik, mahasiswa harus menguasai prinsip maupun konsep tentang bioteknologi konvensional secara mendalam. Melalui kegiatan praktikum, mahasiswa juga dilatih untuk memiliki kemampuan dalam menganalisis kesesuaian antara konsep yang dipelajari atau teori dengan hasil praktikum. Apabila produk yang dihasilkan dari kegiatan praktikum tidak sesuai dengan yang diharapkan, secara tidak langsung mahasiswa akan belajar menganalisis faktor-faktor penyebabnya yang kemungkinan berasal dari langkah-langkah yang kurang tepat saat praktikum. Kegiatan tersebut berkontribusi dalam meningkatkan hasil belajar mahasiswa.

\section{Minat Berwirausaha}

Minat berwirausaha merupakan suatu ketertarikan, keinginan serta kesediaan untuk melakukan kerja keras atau berkemauan keras untuk berusaha maksimal dalam pemenuhan kebutuhan hidup dengan tidak takut terhadap resiko, serta memiliki kemauan belajar dari kegagalan (Fu'adi et al., 2009). Lebih lanjut, Mahesa \& Rahardja (2012) dalam penelitiannya memaparkan minat berwirausaha sebagai kecenderungan hati untuk tertarik membentuk suatu usaha yang selanjutnya mengatur, mengorganisir, menghadapi risiko dan meningkatkan usaha yang telah dibentuk. Berikut ini disajikan hasil analisis data skor minat berwirausaha mahasiswa selama praktikum pembuatan nata dari buah semangka dan tomat.

Tabel 3. Skor Minat Berwirausaha Mahasiswa

\begin{tabular}{llll}
\hline \multirow{2}{*}{ No. } & \multirow{2}{*}{ Kode Mahasiswa } & \multicolumn{2}{l}{ Skor Minat Berwirausaha } \\
\cline { 3 - 4 } & & Siklus I & Siklus II \\
\hline 1. & AS & 70.41 & 83.08 \\
\hline 2. & SL & 65.33 & 68.08 \\
\hline 3. & EPA & 67.58 & 70.62 \\
\hline 4. & AGB & 68.72 & 72.38 \\
\hline 5. & EKTW & 59.08 & 76.54 \\
\hline 6. & NAFH & 78.62 & 83.85 \\
\hline 7. & Al & 53.55 & 66.15 \\
\hline 8. & DMP & 70.06 & 78.08 \\
\hline 9. & DNNF & 73.61 & 77.69 \\
\hline 10. & RA & 82.30 & 85.38 \\
\hline 11. & UM & 80.72 & 86.15 \\
\hline 12. & Su & 76.84 & 80.46 \\
\hline 13. & NF & 73.23 & 82.69 \\
\hline 14. & FD & 56.78 & 68.15 \\
\hline & Rerata & 69.77 & 77.09 \\
\hline & & &
\end{tabular}

Berdasarkan Tabel 3 dapat diketahui bahwa minat berwirausaha mahasiswa pada siklus I sebesar 69.77 meningkat pada siklus II menjadi 77.09. Berikut ringkasan rerata skor minat berwirausaha mahasiswa dipaparkan dalam Gambar 7. 


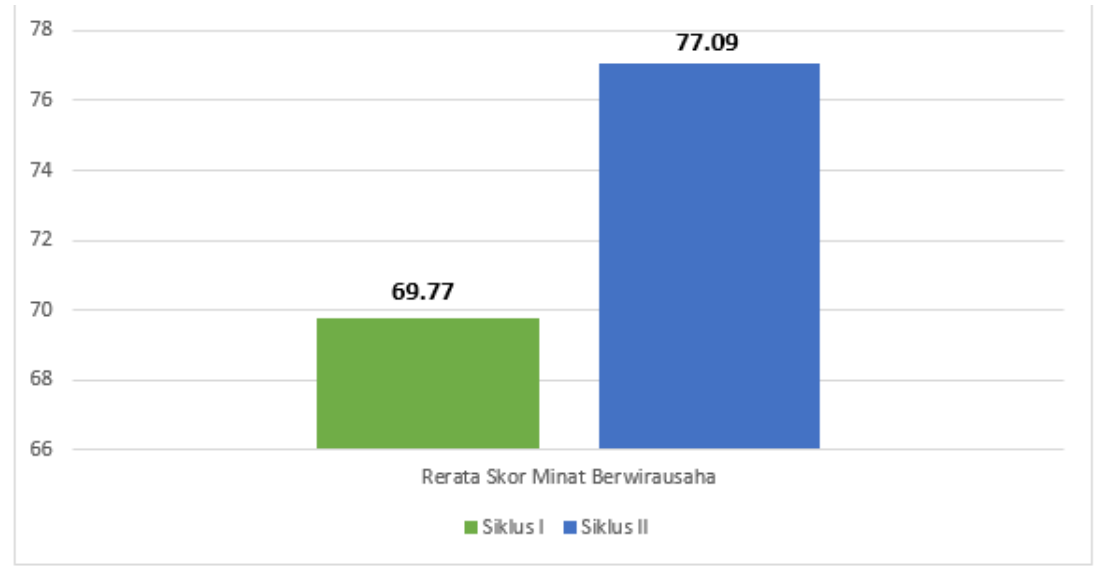

Gambar 7. Rerata Skor Minat Berwirausaha Mahasiswa

Menurut Wibowo (2011), terdapat dua cara untuk menanamkan mental entrepreneurship pada mahasiswa, yaitu mengintegrasikan pendidikan kewirausahaan ke dalam kurikulum dan menyelenggarakan kegiatan ekstrakurikuler yang sistematis dan terarah untuk membangun motivasi dan sikap mental kewirausahaan mahasiswa. Pada penelitian ini, pendidikan kewirausahaan diimplementasikan ke dalam matakuliah Bioteknologi melalui pembelajaran biotechnopreneurship. Dengan pembelajaran biotechnopreneurship mahasiswa diharapkan memiliki minat yang tinggi dalam berwirausaha sebagaimana yang disampaikan oleh Suhartini, (2011); Fatimah \& Purdianto (2020) melalui hasil penelitiannya, bahwa terdapat pengaruh antara pendidikan kewirausahaan dengan minat berwirausaha. Seseorang yang menempuh pendidikan kewirausahaan akan memahami manfaat menjadi wirausaha dan akan semakin tertarik untuk menjadi wirausaha.

Machin (2012) memaparkan bahwa pengukuran kemampuan berwirausaha melalui pembelajaran berbasis bioentrepreneurship mencakup: (1) eksplorasi peluang usaha; (2) penentuan alat dan bahan untuk pembuatan produk; (3) perencanaan pembuatan produk; (4) pembuatan produk berdasarkan rencana; (5) inovasi produk usaha; (6) analisis keuntungan usaha; (7) penemuan rasa terbaik melalui uji organoleptik, dan (8) evaluasi kekurangan dan kelebihan produk yang dibuat.

Pada penelitian ini, mahasiswa telah melakukan analisis peluang usaha yang muncul dari pembuatan nata de citrullus dan nata de tomato sehingga pada akhirnya memilih untuk mengolah nata yang dihasilkan menjadi es buah nata yang menarik. Mahasiswa merencanakan dan menyiapkan sendiri alat serta bahan yang diperlukan untuk mengolah nata hasil praktikum. Selanjutnya mahasiswa melakukan inovasi berupa penambahan buah-buahan yang memiliki warna kontras seperti nanas, buah naga, pepaya dan semangka, serta larutan sirup untuk dicampur dengan nata. Selain itu, inovasi juga tampak dari pengemasan menggunakan cup dan pemberian label pada cup tersebut. Mahasiswa juga melakukan uji organoleptic meliputi tekstur nata, warna nata, rasa nata dan aroma nata. Penambahan berbagai jenis buah dan larutan sirup bertujuan untuk mendapatkan citarasa yang paling baik dari produk yang akan dipasarkan. Sebelum dipasarkan, mahasiswa juga memperhitungkan keuntungan yang akan didapatkan dari penjualan. Kegiatan selanjutnya adalah pemasaran produk di lingkungan kampus. Dari hasil pemasaran, selain memperoleh keuntungan mahasiswa juga mendapatkan saran dan masukan dari pembeli atas produk. Saran yang diberikan oleh pembeli selanjutnya menjadi bahan analisis untu memperbaiki kualitas produk selanjutnya.

Minat berwirausaha tidak lahir dari manusia tetapi tumbuh dan berkembang sesuai dengan itu faktor-faktor yang mempengaruhinya (Kusumajanto, 2015). Faktor-faktor yang mempengaruhi minat 
berwirausaha menurut hasil penelitian Yasmin et al. (2017) di antaranya variabel sikap dan perilaku (attitude), norma subjektif dan kontrol diri. Faktor lainnya meliputi ekspektasi pendapatan (Afrizal et al., 2018), pendidikan kewirausahaan dan lingkungan keluarga (Afrizal et al., 2018; Fatimah \& Purdianto, 2020; Ranwala, 2016; Periansya, 2018), motivasi intrinsik, kepribadian, program kewirausahaan (Periansya, 2018). Lebih lanjut dinyatakan Torres et al. (2017) bahwa niat dalam kewirausahaan merupakan kunci memahami kewirausahaan yaitu memberikan motivasi kepada orang untuk menjadi wirausaha, sehingga dapat dikatakan bahwa niat yang besar untuk berwirausaha berperan dalam membangkitkan motivasi berwirausaha.

\section{KESIMPULAN}

Implementasi model pembelajaran berbasis biotechnopreneurship berpotensi meningkatkan hasil belajar dan minat berwirausaha mahasiswa prodi pendidikan IPA UNHASY Jombang. Skor hasil belajar siklus I sebesar 73.07 mengalami peningkatan menjadi 77.35 pada siklus II. Prosentase ketuntasan hasil belajar pada siklus I sebesar $42.85 \%$ dan meningkat menjadi $64.28 \%$. Skor minat berwirausaha sebesar 69.77 pada siklus I dengan kriteria netral, meningkat menjadi 77.09 dengan kriteria baik. Mengacu pada kekurangan hasil penelitian ini, maka perlu dilakukan perbaikan pembelajaran biotechnopreneurship yang lebih membekali mahasiswa dengan kegiatan analisis keuangan yang detail dan sistematis.

\section{UCAPAN TERIMA KASIH}

Ucapan terimakasih penulis sampaikan kepada Lembaga Penelitian dan Pengabdian Kepada Masyarakat Universitas Hasyim Asy'ari Tebuireng Jombang atas pendanaan yang diberikan sesuai dengan Kontrak Penelitian dan Pengabdian Kepada Masyarakat tahun anggaran 2018 Nomor: 178/LPPM-UNHASY/VIII/2018.

\section{DAFTAR PUSTAKA}

Afriadi, R., \& Yuni, R. (2018). Pengembangan Jiwa Bioentrepreneur Mahasiswa Biologi. Biolokus, 1(2), 123-127. https://doi.org/10.30821/biolokus.v1i2.353

Afrizal, Rafiy, M., \& Nusantara, A. W. (2018). Faktor-faktor yang Mempengaruhi Minat Berwirausaha (Studi Kasus Mahasiswa Fakultas Ekonomi dan Bisnis UHO). JEP (Jurnal Ekonomi Pembangunan), 8(1), 1-11.

Aidha, Z. (2016). Pengaruh Motivasi Terhadap Minat Berwirausaha Mahasiswa Fakultas Kesehatan Masyarakat Universitas Islam Negeri Sumatera Utara. Jumantik, 1(1), 42-59.

Anam, C., Zaman, M. Z., \& Khoirunnisa, U. (2019). Mengungkap Senyawa pada Nata de Coco sebagai Pangan Fungsional. Jurnal IImu Pangan Dan Hasil Pertanian, 3(1), 42-53. https://doi.org/10.26877/jiphp.v3i1.3453

Angraini, E., Mustika, S., Indrayeni, W., \& Elida. (2020). Analisis Gizi Nata de Citrullus dari Semangka Afkir. 12(1), 67-75.

Anwar, M., Supardi, \& Sugiharti, D. Y. P. (2012). Pengembangan Perangkat Pembelajaran Biologi dengan Pendekatan Bioenterpreneurship untuk Meningkatkan Keterampilan Proses IImiah dan Minat Berwirausaha Siswa. Innovative Journal of Curriculum and Educational Technology, 1(1), 38-44.

Budiati, Y., Yani, T. E., \& Universari, N. (2012). Minat Mahasiswa menjadi Wirausaha (Studi pada 
Mahasiswa Fakultas Ekonomi Universitas Semarang). Dinamika Sosbud, 14(1), 89-100.

Fatimah, S. E., \& Purdianto, A. (2020). Factors Affecting Entrepreneurial Interest Among Students in Higher Education. Advances in Economics, Business and Management Research, 123, 145-147. https://doi.org/10.2991/aebmr.k.200305.036

Fifendy, M., \& Annisah, N. (2012). Kualitas Nata de Citrullus dengan Menggunakan Berbagai Macam Starter. Sainstek, IV(2), 158-164.

Fitri, E. E., Ratnasari, E., \& Budijastuti, W. (2014). Pengembangan LKS Bioentrepreneurship Pembuatan Nata de Lerri Materi Biotekologi Konvensional Kelas XII SMA. BioEdu: Berkala IImiah Pendidikan Biologi, 3(3), 416-424.

Fitriah, E. (2013). Implementasi Bioentrepreneurship pada Pembelajaran Biologi untuk Meningkatkan Life Skills dan Minat Wirausaha Siswa Madrasah Aliyah Berbasis Pesantren di Cirebon. Scientiae Uducatia, 2(1), 1-19.

Fu'adi, I. F., Eko, B., \& Murdani. (2009). Hubungan Minat Berwirausaha dengan Prestasi Praktik Kerja Industri Siswa Kelas XII Teknik Otomotif SMK Negeri 1 Adiwerna Kabupaten Tegal Tahun Ajaran 2008/2009. Jurnal Pendidikan Teknik Mesin Unnes, 9(2), 92-98.

Hasni. (2018). Urgensi Pendidikan Kewirausahaan dalam Menghasilkan Wirausahawan Muda dari Perguruan Tinggi. Ekspose, 17(2), 653-664. https://doi.org/10.30863/ekspose.v17i2.121

Huang, L., \& Knight, A. P. (2017). Resources and Relationships in Entrepreneurship: An Exchange Theory of the Development and Effects of the Entrepreneur-Investor Relationship. The Academy of Management Review, 42(1), 80-102. https://doi.org/10.5465/amr.2014.0397

Islam, M. A., Khan, M. A., Obaidullah, A. M. M., \& Alam, M. S. (2011). Effect of Entrepreneur and Firm Characteristics on the Business Success of Small and Medium Enterprises (SMEs) in Bangladesh. International Journal of Business and Management, 6(3), 289-299.

Isrososiawan, S. (2013). Peran Kewirausahaan dalam Pendidikan. Society, Jurnal Jurusan Pendidikan IPS Ekonomi, ix, 26-49.

Kusumajanto, D. D. (2015). The Role of Entrepreneurship Education and Self Efficacy in Shaping Student Interest in Doing Entrepreneurship. European Journal of Business and Management, 7(28), 153-158.

Lestari, R. B., \& Wijaya, T. (2012). Pengaruh Pendidikan Kewirausahaan terhadap Minat Berwirausaha Mahasiswa di STIE MDP, STMIK MDP, dan STIE MUSI. Forum Bisnis Dan Kewirausahaan Jurnal IImiah STIE MDP, 1(2), 112-119. https://doi.org/10.31227/osf.io/kejft

Machin, A. (2012). Pengembangan Model Pembelajaran Bioteknologi Bervisi Kewirausahaan di Sekolah Menengah Atas. Bioedukasi, 5(2), 50-60.

Mahesa, A. D., \& Rahardja, E. (2012). Analisis Faktor-Faktor Motivasi yang Mempengaruhi Minat Berwirausaha. Diponegoro Journal of Management, 1(1), 130-137. http://www.ejournals1.undip.ac.id/index.php/djom/article/view/787

Mopangga, H. (2015). Studi Kasus Pengembangan Wirausaha Berbasis Teknologi (Technopreneurship) di Provinsi Gorontalo. Trikonomika, 14-24. http://www.journal.unpas.ac.id/index.php/trikonomika/article/view/587

Natalia, R. D., \& Parjuningtyas, S. (2009). Bahan Baku Pembuatan Nata De Tomato. In Seminar Tugas Akhir S1 Jurusan Teknik Kimia, Fakultas Teknik, Universitas Diponegoro.

Ningsih, R. (2017). Peranan Pendidikan Kewirausahaan dalam Meningkatkan Motivasi Berwirausaha Mahasiswa. Prosiding Diskusi Panel Nasional Pendidikan Kewirausahaan LPPM Universitas 
Indraprasta PGRI Jakarta, 60-69.

Nur, N., Surachman, Salim, U., \& Djumahir. (2014). Entrepreneurship Orientation, Market Orientation, Business Strategy, Management Capabilities On Business Performance; Study At Small And Medium Enterprise Printing In Kendari. International Journal of Business and Management Invention, 3(12), 08-17.

Okorie, N. N., Kwa, D. Y., Olusunle, S. O. O., Akinyanmi, A. O., \& Momoh, I. M. (2014). Technopreneurship: An Urgent Need in the Material World for Sustainability in Nigeria. European Scientific Journal, 10(30), 59-73.

Periansya. (2018). Analysis of Effect of Education Entrepreneurship and Family Environment Towards Interest Students Entrepreneurs. Jurnal Terapan Manajemen Dan Bisnis, 4(1), 25-32. https://doi.org/10.26737/jtmb.v4i1.488

Rahayu, E. P. (2011). Pembuatan Tempe sebagai Sumber Belajar Sub Materi Bioteknologi untuk Menarik Minat Berwirausaha Siswa SMA Negeri 1 Tunjungan Blora. Jurusan Biologi FMIPA Universitas Negeri Semarang.

Ranwala, R. S. (2016). Family Background, Entrepreneurship Specific Education and Entrepreneurial Knowledge in Venture Creation. International Journal of Scientific and Research Publications, 6(9), 495-501.

Subekti, H., \& Hidayati, S. N. (2013). Integrasi Biotecnopreneurship untuk Mendukung Kompetensi Calon Guru Sains. Konferensi Nasional "Inovasi Dan Technopreneurship" IPB International Convention Center, February, 1-13.

Suhartini, Y. (2011). Analisis Faktor-faktor yang Mempengaruhi Minat Mahasiswa Dalam Berwiraswasta (Studi pada Mahasiswa Universitas PGRI Yogyakarta). Akmenika Upy, 7, 38-59.

Suyahman. (2017). Penguatan Karakter Kewirausahaan melalui Pendidikan Keluarga. Jurnal Pendidikan IImu Sosial, 27(1), 11-18.

Torres, F. C., Méndez, J. C. E., Barreto, K. ., Chavarría, A. P., Machuca, K. J., \& Guerrero, J. A. O. (2017). Exploring entrepreneurial Intentions in Latin American University Students. International Journal of Psychological Research, 10(2), 46-59. https://doi.org/10.21500/20112084.2794

Volery, T., Mueller, S., \& Siemens, B. V. (2013). Entrepreneur Ambidexterity: A Study of Entrepreneur Behaviours and Competencies in Growth-Oriented Small and Medium-Sized Enterprises. International Small Business Journal, May, 1-21. https://doi.org/10.1177/0266242613484777

Wibowo, M. (2011). Pembelajaran Kewirausahaan dan Minat Wirausaha Lulusan SMK. Eksplanasi, 6(2), 109-122. https://doi.org/10.31932/ve.v8i2.42

Widiyaningrum, P., Mustikaningtyas, D., \& Priyono, B. (2017). Evaluasi Sifat Fisik Nata de Coco Dengan Ekstrak Kecambah Sebagai Sumber Nitrogen. Seminar Nasionar Pendidikan, Sains Dan Teknologi FMIPA Universitas Muhammadiyah Semarang, 234-239.

Widyastuti, Sampurno, B., \& Ferdiansyah, A. P. (2016). Integrasi Teknologi \& Entrepreneurship (menuju ITS Entrepreneurial University). Surabaya: Pusat Aktivitas Kemahasiswaan (PAK) LP2KHA ITS.

Yasmin, A., Najamuddin, M., \& Sari, R. A. P. (2017). Analisis Faktor-Faktor yang Mempengaruhi Mahasiswa untuk Berwirausaha (Studi Kasus Mahasiswa Agribisnis UIN Syarif Hidayatullah Jakarta). Agribisnis, 11(7), 202-217. https://doi.org/10.15408/aj.v12i2.11864

Zubaedi. (2015). Urgensi Pendidikan Kewirausahaan di Kalangan Mahasiswa PTKI. Madania, 19(2), 147-158.https://www.mendeley.com/viewer/. 